\title{
The Role and Activities of the Hellenic Red Cross During the First Five Years of the Economic Crisis in Greece (2010-2014) —A Retrospective Study
}

\author{
Ioannis A. Tagarakis \\ Postgraduate Master's Degree Program, Health and Social Care Services Management, \\ Aristotle University of Thessaloniki, Greece \\ E-mail: tagio1998@gmail.com \\ Georgios I. Tagarakis \\ Postgraduate Master's Degree Program, Health and Social Care Services Management, \\ Aristotle University of Thessaloniki, Greece \\ E-mail: gtagarakis@gmail.com
}

Received: Nov. 23, 2021 Accepted: Dec. 29, 2021 Published: Jan. 9, 2022

doi:10.5296/ijssr.v10i1.19293 URL: https://doi.org/10.5296/ijssr.v10i1.19293

\begin{abstract}
Aim. To investigate the contribution of the Hellenic Red Cross to the Greek Society during the first five and more severe years (2010-2014) of the profound financial crisis in Greece. Material And Methods. We retrospectively investigated the actions and contribution of the Hellenic Red Cross for the aforementioned five-year period. The research material was accumulated by research in the Internet, the archives, and the official webpage of the Hellenic Red Cross (Google, official web page of the ICRC and IFRC), from the Hellenic Ministry of Health and the Hellenic Ministry of Immigration and Asylum. Results. A huge amount of over 247 actions were detected for the research period. More than 17,708 people were examined and treated from the specialized medical personnel of the Hellenic Red Cross and 3,266 individuals were trained in basic first aid and hygiene. The final amount of $297,757 €$ were donated and 5,880 welfare packages were delivered. Conclusions. The current study has concluded that the contribution of the Hellenic Red Cross to the Greek society during the most severe phase of the recent financial crisis was outstanding and consists an example for any other Non-Governmental, Non for Profit Organizations in the future.
\end{abstract}

Keywords: Hellenic Red Cross, social contribution, non-governmental organization, non-profit organization 


\section{Introduction}

The International Red Cross and Red Crescent Movement (French: Mouvement International de la Croix-Rouge et du Croissant-Rouge), called the Red Cross for short, is a humanitarian movement which today includes a number of organizations with common goals. It consists of the International Committee of the Red Cross (ICRC), the International Federation of Red Cross and Red Crescent Societies (IFRC) and 188 National Red Cross and Red Crescent departments. The oldest organization within the movement is the (ICRC), which was founded in 1863 as a private humanitarian organization by five prominent Geneva citizens under the guidance of Henry Dunant. Its original name was "International Committee for the Relief of Injuries" and it received its current name in 1876.

Since that date, the Red Cross has offered significant humanitarian aid, by providing treatment to injured and seriously ill patients, by acting as a mediator for the exchange of prisoners of war throughout the globe, by protecting and by providing care to refugees and other vulnerable social groups.

Shortly after the international appearance of the organization, the Hellenic Red Cross was founded on June 10, 1877, based on the initiative of Queen Olga of Greece. It is a part of the ICRC and the IFRC and it is tightly connected with the other 187 National Red Cross and Red Crescent Departments. It has offered notable humanitarian aid throughout the Greek History to war victims, both military and civilian, to prisoners, refugees and to vulnerable social groups in general. It consists of three Bodies: the Volunteer Nurse Core, the Volunteer SamaritansRescuers and Lifeguards Core and the Volunteer Social Welfare Core. It has also founded and managed three major general hospitals in the national capital area of Athens which are still fully operational today.

In the current paper, we have investigated the multiple activities of the Hellenic Red Cross during the first five severe years (2010-2014) of the profound financial crisis inflicted on the country, both as a result of the global crisis as well as a result of chronic intrinsic structural disorders of the Greek financial and political system (Levy Economics Institute of Bard College).

\section{Literature Review/Methodology}

The research includes data for the afore mentioned five-year period which corresponds to the five first and most severe years of the economic crisis. Our research was based on material accumulated from research on the Internet, the archives, and the official webpage of the Hellenic Red Cross (Hellenic Red Cros, webpage, Bulletin 2010-2014) (Google, official web page of the ICRC and IFRC), from the Hellenic Ministry of Health and the Hellenic Ministry of Immigration and Asylum.

\section{Results and Findings}

In the research period we have found the following data:

For the year 2010, the Hellenic Red Cross undertook 20 social activities. The physicians and the specialized personnel of the Hellenic Red Cross examined or treated 2,353 patients. 
During that year the organization trained 1,400 people in basic hygiene and first aid. The amount of money donated to actions was $282,977,80 €$ and the value of the welfare packages delivered was $10,000 €$. From the 20 social activities 15 were meant for children/ refuges and other vulnerable groups.

In 2011 the Hellenic Red Cross carried out 18 social activities. During that year the organization trained 327 individuals in basic hygiene and first aid. The number of packages delivered was 1,400. From the 18 social activities 10 were meant for children/ refuges and other vulnerable groups.

In 2012 the organization performed 14 social activities. During that year the Hellenic Red Cross trained 260 individuals in basic hygiene and first aid. The number of packages delivered was 1,400 . From the 14 social activities 10 were meant for children/refuges and other vulnerable groups.

For the year 2013 the Hellenic Red Cross carried out 83 social activities. The doctors and the specialized personnel of the Hellenic Red Cross examined or treated 15,251 patients. During that year the organization trained 1,249 people in basic hygiene and first aid. In that year 1.765 packages and 24 tons of food were delivered. From the 83 social activities, 73 were meant for children/refuges and other vulnerable groups

For the final year of our research, the Hellenic Red Cross made 112 social activities. The doctors and the specialized personnel of the Hellenic Red Cross examined or treated 104 patients. During that year the organization trained 30 people in basic hygiene and first aid. The amount of money donated to actions was $14,780 €$ and 1,315 welfare packages were delivered in addition to 90 tons of humanitarian aid packages. From the 110 social activities 100 were meant for children/refuges and other vulnerable groups. (The aforementioned results are depicted on Table 1.)

As can be seen from the thorough research of the existing data the role of the Hellenic Red Cross is multifarious. During the financial crisis, a large number of people requested help from the organization due to the insufficiency of the state structures and services. The results of the research (Hellenic Red Cros, webpage) are a stone proof for the active role of the Hellenic Red Cross (HRC) in the society.

In order to gather the results, there were many problems to overcome, mainly because it was a retrospective research based on the registered archives of the Hellenic Red Cross. Any possible shortcomings are due to the fact that this study concerns the first 5 years of the financial crisis, and it was not a priority of the organization to thoroughly record all the actions and their data. However, the effort was made to find, collect and record the existing data in order to provide a first scientific study on that subject.

Nevertheless, the existing details are enough to prove that the role of the organization in the society during the first years of the economic crisis was huge and, in many cases, decisive for the Greek society (Hellenic Red Cros, webpage). 


\section{Conclusion and Recommendations}

The current study has concluded that the contribution of the Hellenic Red Cross to the Greek society (Athens Coordination Centre for Migrant and Refugees, web page) during the most severe phase of the recent financial crisis (Levy Economics Institute of Bard College, webpage) was outstanding and consists of an example for any other non-Governmental, non-for-Profit Organizations in the future. In the era of globalization, economic crisis, and extreme refugee waves towards financially developed countries the role of non-governmental organizations (NGO) has become more prominent both in a national as well as in the international level. Government agencies and NGO should find the optimal ways to cooperate with each other for the benefit of human beings in need. The activities and contribution of the Hellenic Red Cros to the Society and its's pattern of cooperation with the Hellenic State pose a positive example for this type of parallel action.

Table 1. The table depicts yearly cumulative data on the actions of the Hellenic Red Cross for the period 2010-2014. The basic categories of action are separately covered.

\begin{tabular}{|c|c|c|c|c|c|c|}
\hline YEAR & $\begin{array}{l}\text { Number } \\
\text { of actions }\end{array}$ & $\begin{array}{l}\text { Number of } \\
\text { patients } \\
\text { /subjects } \\
\text { treated/ } \\
\text { examined }\end{array}$ & $\begin{array}{l}\text { Number } \\
\text { of } \\
\text { subjects } \\
\text { trained }\end{array}$ & $\begin{array}{l}\frac{\text { Amount of }}{\text { money }} \\
\text { donated to } \\
\text { actions }\end{array}$ & $\begin{array}{l}\text { Number or value } \\
\text { of packages } \\
\text { delivered }\end{array}$ & $\begin{array}{l}\text { Various activities } \\
\text { (e.g., amusement } \\
\text { facilities for } \\
\text { children and other } \\
\text { vulnerable groups } \\
\end{array}$ \\
\hline 2010 & 20 & 2,353 & 1,400 & $282,977,80 €$ & $10,000 €$ & 15 \\
\hline 2011 & 18 & $\begin{array}{l}\text { (Not available } \\
\text { information) }\end{array}$ & 327 & $\begin{array}{l}\text { (Not available } \\
\text { information) }\end{array}$ & $\begin{array}{l}\text { 1,400 packages } \\
\text { delivered }\end{array}$ & 10 \\
\hline 2012 & 14 & $\begin{array}{l}\text { (Not available } \\
\text { information) }\end{array}$ & 260 & $\begin{array}{l}\text { (Not available } \\
\text { information) }\end{array}$ & $\begin{array}{l}\text { 1,400 packages } \\
\text { delivered }\end{array}$ & 9 \\
\hline 2013 & 83 & 15,251 & 1,249 & $\begin{array}{l}\text { (Not available } \\
\text { information) }\end{array}$ & $\begin{array}{l}1,765 \text { packages } \\
\text { delivered, } \\
24 \text { tons of food }\end{array}$ & 73 \\
\hline 2014 & 112 & 104 & 30 & $14,780 €$ & $\begin{array}{l}1,315 \\
\text { packages delivered, } \\
90 \text { tons of } \\
\text { humanitarian aid }\end{array}$ & 100 \\
\hline
\end{tabular}

\section{References}

Athens Coordination Centre for Migrant and Refugees. Retrieved from https://www.accmr.gr/el/\%CF\%85\%CF\%80\%CE\%B7\%CF\%81\%CE $\%$ B5\%CF $\% 83 \% \mathrm{CE} \% \mathrm{~A}$ $\mathrm{F} \% \mathrm{CE} \% \mathrm{~B} 5 \% \mathrm{CF} \% 82 /$ service $/ 333 . \mathrm{html}$

Athens Coordination Centre for Migrant and Refugees. Retrieved from https://www.accmr.gr/el/\%CE\%BC\%CE\%AD\%CE\%BB\%CE\%BF\%CF\%82/team/449.htm

Hellenic Republic, Ministry of Migration and Asylum. Retrieved from https://migration.gov.gr/tag/erythros-stayros

Hellenic Red Cros, webpage, Bulletin 2010-2014. Retrieved from http://www.redcross.gr/default.asp?pid=30\&la=1 


\section{Macrothink}

International Journal of Social Science Research

ISSN 2327-5510 2022, Vol. 10, No. 1

Hellenic Red Cros. Retrieved from http://www.redcross.gr/default.asp?pid=7\&la=1

Hellenic Red Cros. Retrieved from https://www.samarites.gr/?section=1144\&language=el

Levy Economics Institute of Bard College. Retrieved from https://www.levyinstitute.org/greek/regions/?region=3

\section{Copyrights}

Copyright for this article is retained by the author(s), with first publication rights granted to the journal.

This is an open-access article distributed under the terms and conditions of the Creative Commons Attribution license (http://creativecommons.org/licenses/by/4.0/). 